\title{
繰返熱応力に対する耐熱材料の強度に関する研究*
}

\author{
（第 1 報＼cjkstart熱疲労試験機索らびに試験結果）
}

\author{
宇野九十九** 山内 英 和***
}

\section{A Study on the Effects of Cyclic Thermal Stresses on Heat Resisting Metals}

by

\author{
Tsukumo Uno and Hidekazu Yamanouchi \\ (Mitsubishi Shipbuilding and Engineering Co., Ltd)
}

The machinery part which is to be exposed to a high temperature is designed on the basis of creep strength, creep rupture strength and high temperature fatigue strength. However, in the design of jet engine part and other machinery part as well as gas turbine for naval vessels subject to temperature fluctuation because of many start-and-stops, the above data are not sufficient, and data on cyclic thermal stress are required. This is an interim report on the tests we have been making on three kinds of heat resisting material by means of thermal fatigue test apparatuses manufactured to meet this requirement. The test apparatuses used are indirect heating thermal cycling test apparatuses, direct heating thermal cycling test apparatuses and a high temperature constant strain cycling test apparatus; the indirect heating thermal cycling test apparatus is mainly used at present. It has been found from the tests that thermal fatigue strength depends to a great extent on heat treatment condition of material, and has no relation with creep rupture strength.

(Received Nov. 16, 1959)

\section{1. 緒言}

高温で使用される機峨部分の設計はいっぱんにクリ ープ強度, クリープ破断強度掞よび高温疲労強度をも とにしてなされる。ところが艦艇用ガスタービンなど は発停が多く, かつ急速起動が要求されるため, 充分 なる暖機の時間が与えられず，その始動のさいにはタ ービン各部に定常運転中よりも大さな温度分布の不均 一を生ずる結果, 高温部には非常に大きな圧縮の熱応 力が生じて材料の降伏およびクリープが起こり, 休止 中にはこれが引張の残留応力となって, 発停ごとに圧 縮と引張が繰り返されることになるが，この繰返熱応 力が過大であればついには材質のぜい化を来たし破損 に至るのである.しかしながら，従来このような点に 関してはほとんど研究されておらず，このような問題 は前述の資料から判断することは困難であり, 䋫返熱 応力に対する強度の資料の必要が痛感される.

延性材料に対する熱疲労の研究は L.F. Coffin が 18-8-Cb 材につき本格的研究を行なっているのがはじ まりである。

筆者らは自動温度制御電気炉を有する繰返熱応力試

\footnotetext{
* 原稿受付 昭和 34 年 11 月 16 日

** 三苳造船株式会社本社研究部

*** 正員 三䔖造船株式会社水社研究部
}

験機, 試験片に直接通電する直接加熱式繰返熱応力試 験機および油圧式高温定ひずみ繰返試蛤機を製作し， $650^{\circ} \mathrm{C}$ 付近で使用される 3 種の而熱鋼 $\mathrm{SEH}_{4}$, Timken 16-25-6 および LCN 155 について熱疲労試験を行な っているので, 主として間接加熱式繰返熱応力試験機 を使用して得られた現在までの試験結果を報告する。

\section{2. 試 験 装 置}

\section{（I）間接加熱式繰返熱応力試験機}

試験機 4 台を 1 組として 2 組設置し, 自動温度制御 電気炉により両端を固定した薄肉中空円筒状試験片に 加熱冷却を交互に与えて試験片に熱応力の繰り返しを 生ぜしめるものである. Photo. 1 に試験装置を Fig.

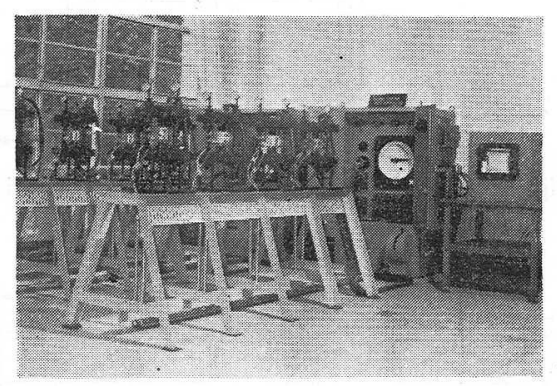

Photo. 1 Indirect heating thermal cycling test apparatus 
1 に試験機の組立図を示す，試験片の形状は Fig. 2 のとおりで試験にさいしてその両端は上，下支持板に 堅く取り付ける.上，下支持板は 2 本の支柱により連 結されているが，曲りの影響を除くため球面座金を用 いている，支柱は中空棒で内部下端にねじ込みされた 棒に, $1 / 1000 \mathrm{~mm}$ ダイアルゲージを取り付けて, 柱 のひずみを計測し試験片の応力を測定している，また， 試験中に試験機が温度変化を受けてひずみの計測に誤 差がはいるのを防ぐため，上，下支持板には冷却水を 循環させて試験機の温度を一定に保っている。

温度調整装置は所要の電流値を得るための加熱電流 調整用リアクター, 上, 下限温度自動調整のための指 示型電子管式温度調節計, 上, 下限温度保持時間調整 用タイマー, 絽返数計測器とうを含むものであって, これらを相互に連動せしめるようにしてあり，かつ冷 却のさいには電磁弁が働さ压縮空気が試験片に吹きつ けられる。試験温度範囲は常温一 $800^{\circ} \mathrm{C} て ゙$, 上, 下限 温度保持時間は上限は $0 \sim 120$ 分, 下限は $0 \sim 30$ 分の 調整範团を有している。

\section{（II） 直接加熱式繰返熱応力試験機}

試験機 3 台が1組になっていて, 両端を固定した薄

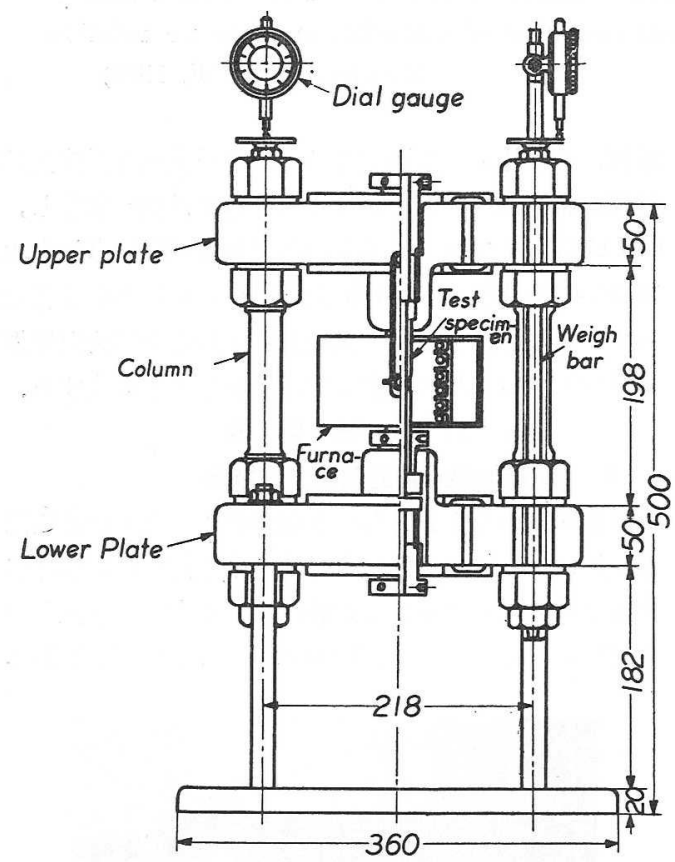

Fig. 1 An indirect heating thermal cycling tester

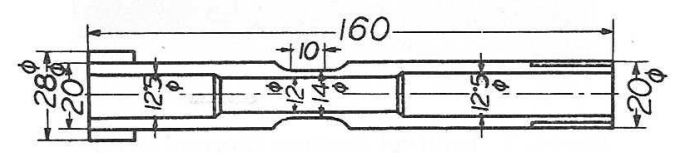

Fig. 2 Test specimen
肉中空円筒状試験片に直接通電して加熱し冷却は強制 通風を行ない，試験時間の短縮を図るとともに，繰返 温度範囲に刘するひずみ範囲を独立に変化させうるよ うにしてある。Photo. 2 に試験装置在 Fig. 3 に試 験機の組立図を示す。試験機の形状は間接加熱式と類 似しているが，支柱に皿ばね在取り付けることにより 試驗片に生ずる繰り返しひずみを变化せしめ，これを 高温マイクロスコープで測定するとともに，試験片の 応力は支柱のひずみを電気抵抗線ひずみ計で計測して 求めている。試験中の温度変化によるひずみの計測誤 差を防ぐため，上，下支持板および支柱には冷却水を 循環させている。

温度調整装置は加熱トランス, 温度調節計, 上, 下 限温度保持時間調整用タイマ一, 緑返数計測器とうを 含み, これらを相互に連動させ, 温度上昇, 上, 下限 温度保持電流がそれぞれ単独に調整できるようになっ ている。試験温度範囲は常温一 $1000^{\circ} \mathrm{C} て ゙$, 上, 下限温

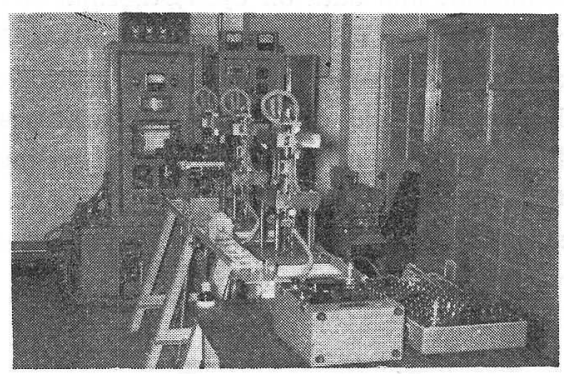

Photo. 2 Direct heating thermal cycling test apparatus

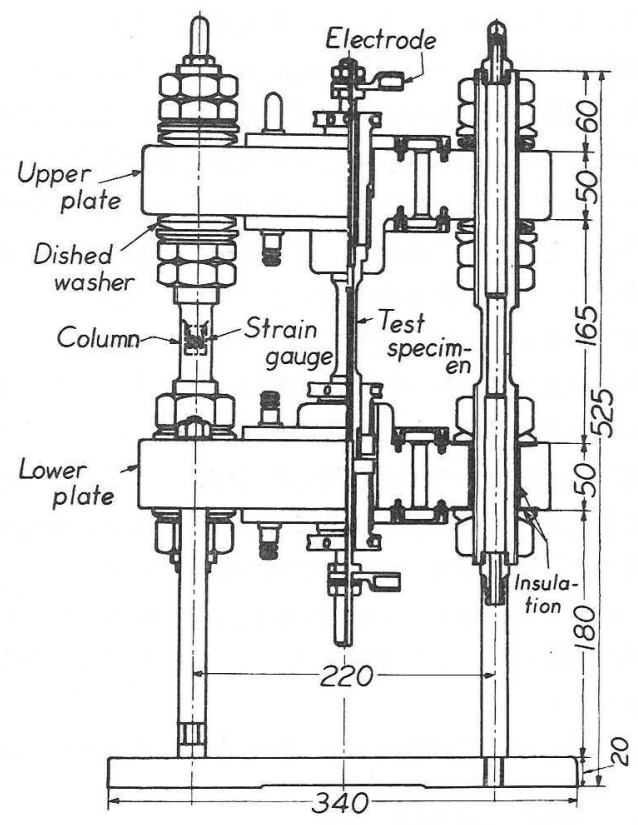

Fig. 3 A direct heating thermal cycling tester 
度保持時間は上限は $0 \sim 60$ 分，下限は 0 ３0 分の調整 範囲を有している。

\section{(III) 高温定ひずみ繰返試験機}

熱けイクルの温度振幅が一定な熱疲労は熱ひずみに 相当する総ひずみが一定の繰り返しを受けるわけであ るから, 一定程度で一定のひずみを繰り返す場合の強 度と, 等疲労強度とを関連させて考えるために設置し たものである、装置は一定温度にある薄肉中空円筒状 試験片の一端をピストン・ロッドに取り付け, 油圧ポ ソプ,ソレノイド・バルブにより引張力および圧縮力 を交互に与え所定のひずみ量に達すると，ひずみ検出 計に内蔵された電気的接点の閉開路により,ソレノイ ド・バルブを切り換えて試験を行なうようになってい る. Photo. 3 に試験装置を Fig. 4 に試験機の組立 図を示す。試験片の下端はピストン・ロッドにねじ込 みされてナットで締め付けられるとともに，上端はボ ルトにより固定される。そこで油圧によるシリンダー

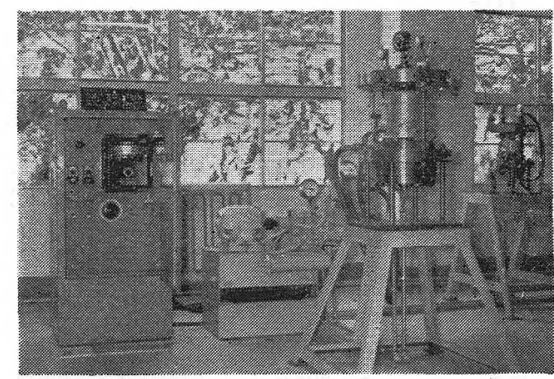

Photo. 3 High temperature constant strain cycling test apparatus

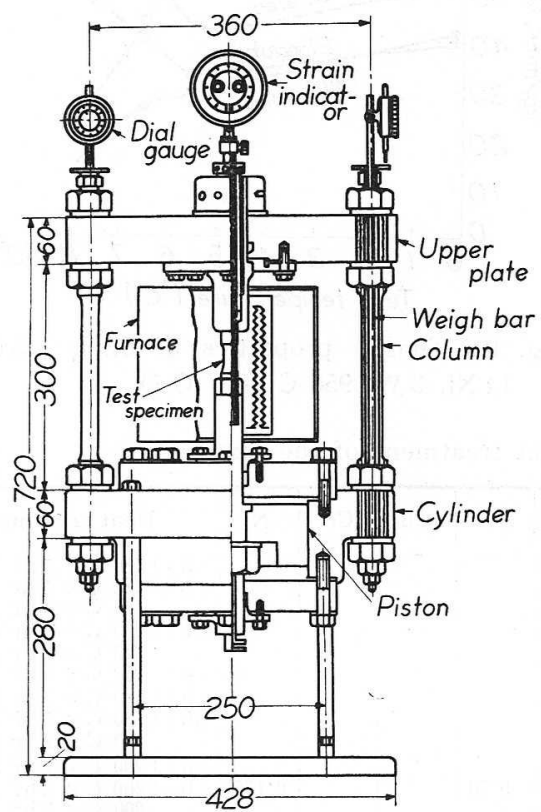

Fig. 4 A high temperature constant strain cycling tester
内のピストンの上下動により，中空試験片内部に取り 付けたひずみ検出棒の動きをひずみ検出計にとらえ， 一定の圧緶, 引張ひずみの繰返しを行なう。試験片の ひずみとひずみ榆出計の目もりとはあらかじめ補正し てある. 試験片の応力は支柱のひずみ党 $1 / 1000 \mathrm{~mm}$ ダイアルゲージで計測して求めている。な拉, 訊験機 の上部支持板およびピストン・ロッドに冷却水を循環 させて試験機の温度を一定に保っている. 試験温度は 常温一 $800^{\circ} \mathrm{C}$ で, 試験速度は 1 サイクル 30 秒一 5 分 まで変えうる。

\section{3. 間接加熱式繰返熱応力試験}

試験片の両端を固定して Fig. 5 のように加熱冷却 サイクルを繰り返し与えるのであるが, 試験片を上限 温度で固定するか下限温度で固定するかによって得ら れるヒステリシス・ループの形が異なる。いっぱんに

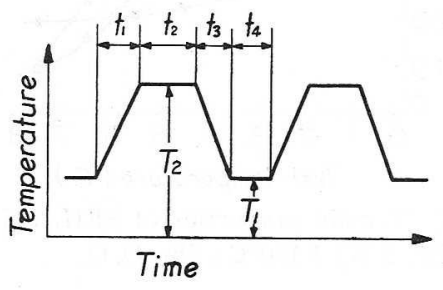

Fig. 5 Thermal cycle

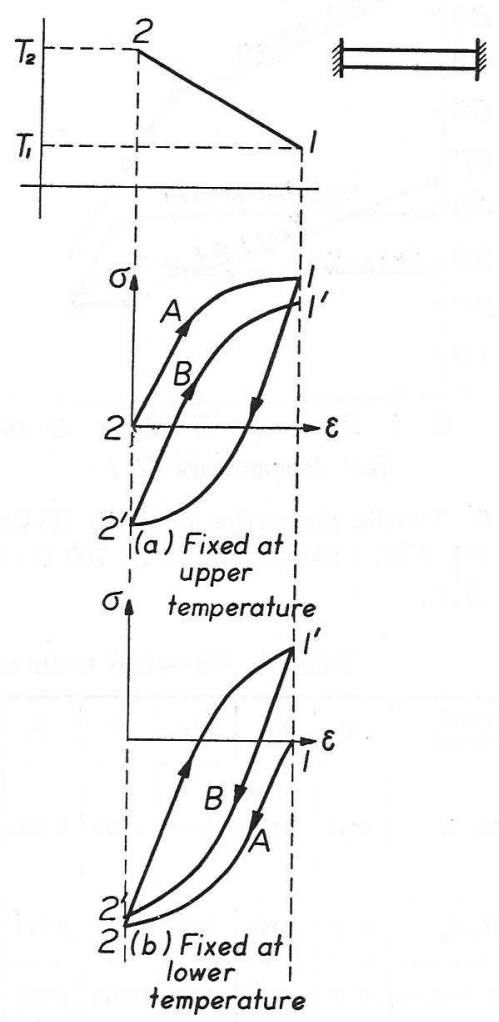

Fig. 6 Stress-strain relation for thermal cycling 
延性材料の温度サイクルによる応力ーひずみ 関係を

Fig. 6 について説明すればつぎのとおりである。 $T_{2}$ を上限温度， $T_{1}$ を下限温度とし $T_{2}$ で試験片を固定 したとする。このとさは(a)図において $T_{2}$ より冷却 されると試験片には引張応力が生じ， $2 \mathrm{~A}$ のようには じめ弾性的についで塑性変形を起こして 1 点に達し, ここで温度 $T_{1}$ に保持される。つぎに温度が上昇を始 めるに従い, 応力は除荷されて圧縮応力に変わり, 温

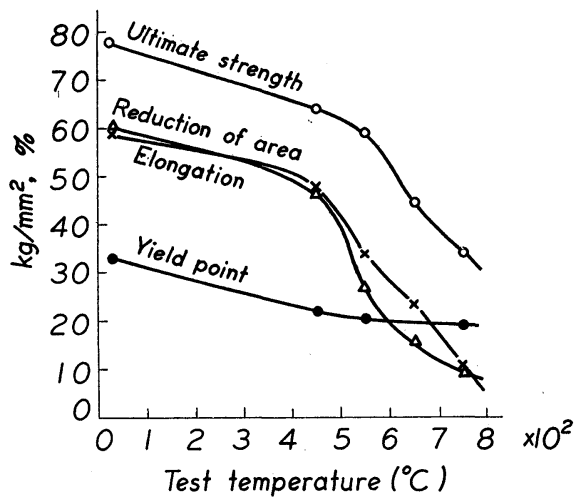

Fig. 7 Tensile properties of $\mathrm{SEH}_{4}(15 \mathrm{Cr}, 14$ $\mathrm{Ni}, 2 \mathrm{~W}) 1180^{\circ} \mathrm{C} \times 5 \mathrm{hr}$ O. Q.

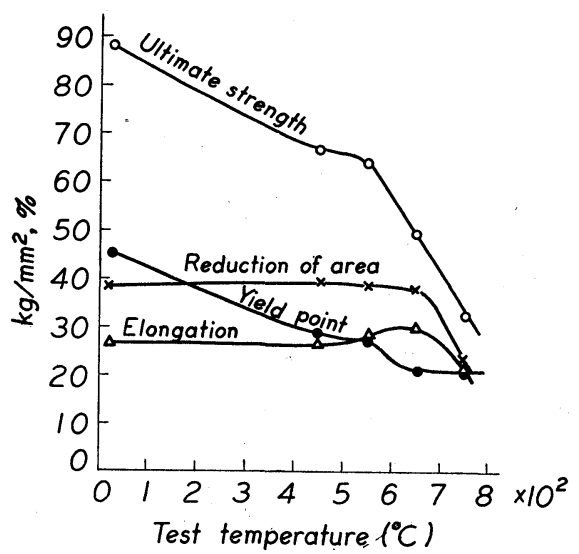

Fig. 8 Tensile properties of $\mathrm{SEH}_{4}(15 \mathrm{Cr}, 14$ $\mathrm{Ni}, 3 \mathrm{~W}) 1180^{\circ} \mathrm{C} \times 5 \mathrm{hr}$ O.Q. $700^{\circ} \mathrm{C} \times 24 \mathrm{hr}$ A. C.
度 $T_{2}$ に戻れば試験片の変形は消失するが， $22^{\prime}$ の大 ささの圧縮応力が残留する，つぎの熱サイクルが始ま れば $2^{\prime} \mathrm{B}$ 線に沿って応力が変化していく．上限の保持 中にはクリープのため応力の減少が起こり，また，熱 サイクル中に生ずる材質変化，バウシンガー効果等の ためヒステリシス曲線の中心はしだいに移動するので あるが, 数サイクル後には一定值に落着く. 試験片を 下限温度で固定した場合は Fig. 6 (b)図のようにな

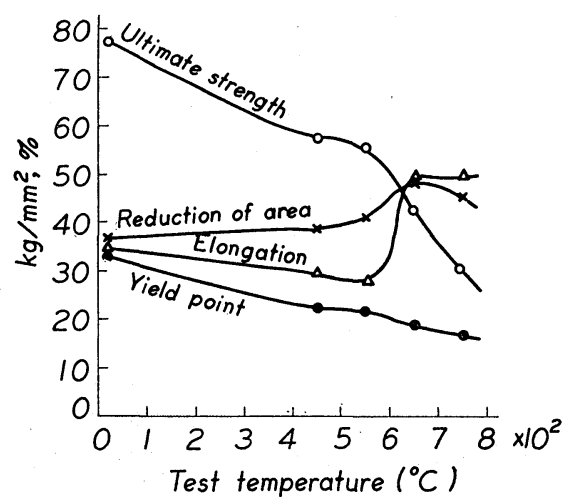

Fig. 9 Tensile properties of $\mathrm{SEH}_{4}(15 \mathrm{Cr}$, $14 \mathrm{Ni}, 3 \mathrm{~W}) 1180^{\circ} \mathrm{C} \times 5 \mathrm{hr}$ O.Q. $850^{\circ} \mathrm{C}$ $\times 32 \mathrm{hr}$ A.C.

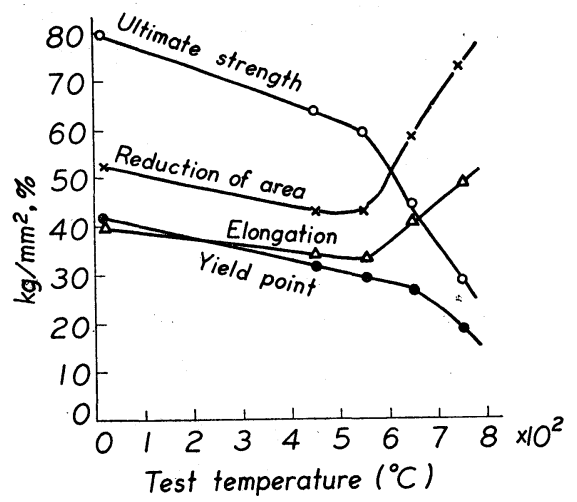

Fig. 10 Tensile properties of $\mathrm{SEH}_{4}(15 \mathrm{Cr}$, $14 \mathrm{Ni}, 3 \mathrm{~W}) 950^{\circ} \mathrm{C} \times 5 \mathrm{hr}$ O.Q.

Table 1 Chemical composition (\%) and heat treatment of the material

\begin{tabular}{|c|c|c|c|c|c|c|c|c|c|c|c|c|c|}
\hline $\begin{array}{l}\text { Material } \\
\& \text { symbol }\end{array}$ & $\mathrm{C}$ & $\mathrm{Si}$ & $\mathrm{Mn}$ & $P$ & $\mathbf{S}$ & $\mathrm{Cr}$ & $\mathrm{Ni}$ & W & Mo & $\mathrm{Cb}$ & Co & $\mathrm{N}$ & Heat treatment \\
\hline $\mathrm{SEH}_{4}-\mathrm{A}$ & $0 \cdot 42$ & $1 \cdot 97$ & $0 \cdot 33$ & $0 \cdot 020$ & $0 \cdot 010$ & $14 \cdot 51$ & $13 \cdot 92$ & $2 \cdot 48$ & & & & & $\begin{array}{l}\text { (a) } 1180^{\circ} \mathrm{C} \times 5 \mathrm{hr} \text { O.Q. } \\
\text { (b) } 1180^{\circ} \mathrm{C} \times 5 \mathrm{hr} \mathrm{O} . \mathrm{Q} . \\
700^{\circ} \mathrm{C} \times 24 \mathrm{hr} \text { A.C. } \\
\text { (c) } 1180^{\circ} \mathrm{C} \times 5 \mathrm{hr} \text { O.Q. } \\
\text { (d) } 850^{\circ} \mathrm{C} \times 32 \mathrm{hr} \text { A.C. } \\
\text { (d) } 950^{\circ} \mathrm{C} \times 5 \mathrm{hr} \text { O.Q. }\end{array}$ \\
\hline $\mathrm{SEH}_{4}-\mathrm{B}$ & 0.39 & $1 \cdot 46$ & $0 \cdot 29$ & $0 \cdot 015$ & $0 \cdot 014$ & $16 \cdot 16$ & $14 \cdot 17$ & $2 \cdot 82$ & & & & & $\begin{array}{r}\text { (a) } 1180^{\circ} \mathrm{C} \times 5 \mathrm{hr} \mathrm{O} . \mathrm{Q} . \\
\text { (b) } 1180^{\circ} \mathrm{C} \times 5 \mathrm{hr} \mathrm{O} \text {.Q. } \\
850^{\circ} \mathrm{C} \times 32 \mathrm{hr} \text { A.C. }\end{array}$ \\
\hline Timken $16-25-6$ & $0 \cdot 10$ & $0 \cdot 39$ & $1 \cdot 49$ & $0 \cdot 012$ & $0 \cdot 014$ & $15 \cdot 41$ & $25 \cdot 11$ & & $5 \cdot 70$ & & & $0 \cdot 175$ & $\begin{array}{rl}\text { (a) } 1200^{\circ} \mathrm{C} \times 2 \mathrm{hr} & \mathrm{O} . \mathrm{Q} . \\
\text { (b) } 1200^{\circ} \mathrm{C} \times 2 \mathrm{hr} \mathrm{O} . \mathrm{Q} . \\
800^{\circ} \mathrm{C} \times 5 \mathrm{hr} \text { A.C. }\end{array}$ \\
\hline LCN 155 & $0 \cdot 11$ & $0 \cdot 72$ & $1 \cdot 50$ & $0 \cdot 025$ & 0.019 & $20 \cdot 39$ & $20 \cdot 20$ & $2 \cdot 02$ & $2 \cdot 82$ & $1 \cdot 02$ & $20 \cdot 75$ & $0 \cdot 145$ & 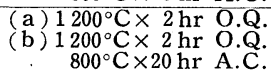 \\
\hline
\end{tabular}




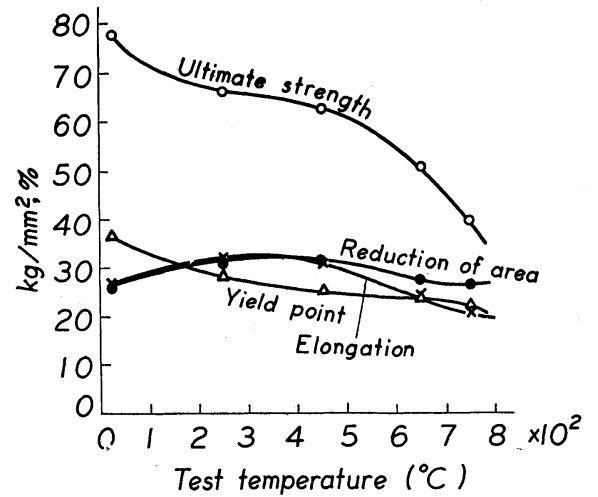

Fig. 11 Tensile properties of Timken 16-25-6 $1200^{\circ} \mathrm{C} \times 2 \mathrm{hr}$ O. Q.

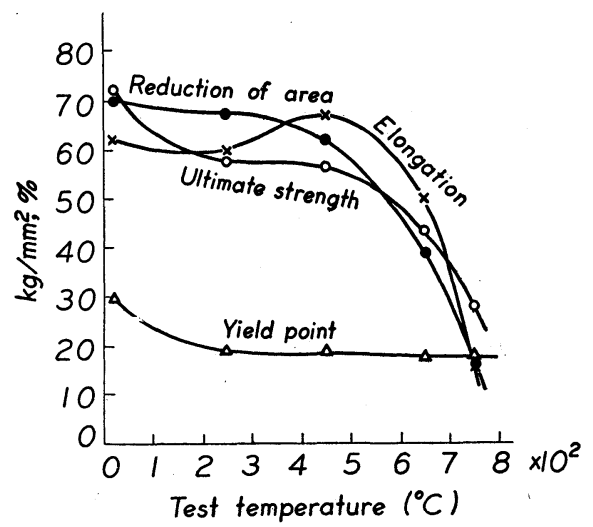

Fig. 12 Tensile properties of Timken 16-25-6 $1200^{\circ} \mathrm{C} \times 2 \mathrm{hr}$ O.Q. $800^{\circ} \mathrm{C} \times 5 \mathrm{hr}$ A.C.

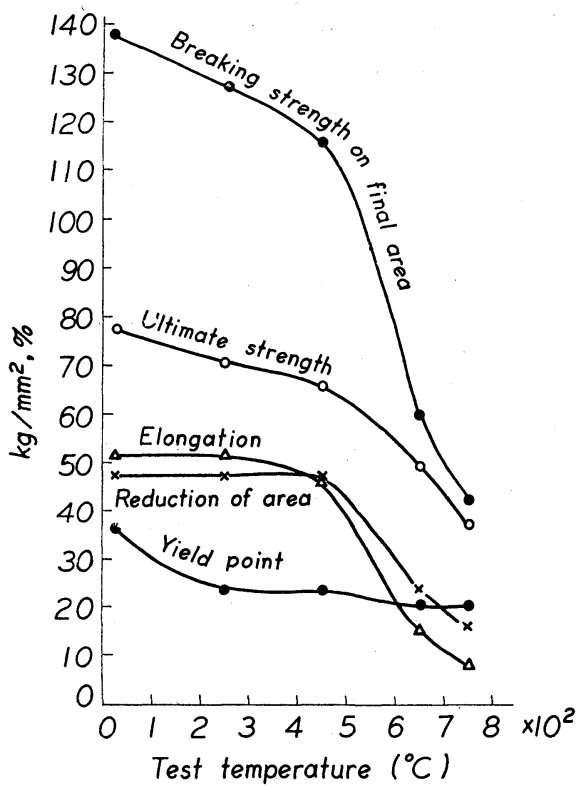

Fig. 13 Tensile properties of $\mathrm{SEH}_{4}(16 \mathrm{Cr}$, $14 \mathrm{Ni}, 3 \mathrm{~W}) 1180^{\circ} \mathrm{C} \times 5 \mathrm{hr}$ O.Q.
ることが理解されよう。熱疲労現象はこの応力ーひず み曲線の大ささ，および形におおいに影響されるもの であって，ループに影響を与える因子を研究すること がたいせつである，重要な因子としては上限，下限の 温度 $T_{1}, T_{2}$ および各温度における保持時間 $t_{1}, t_{4}$ お

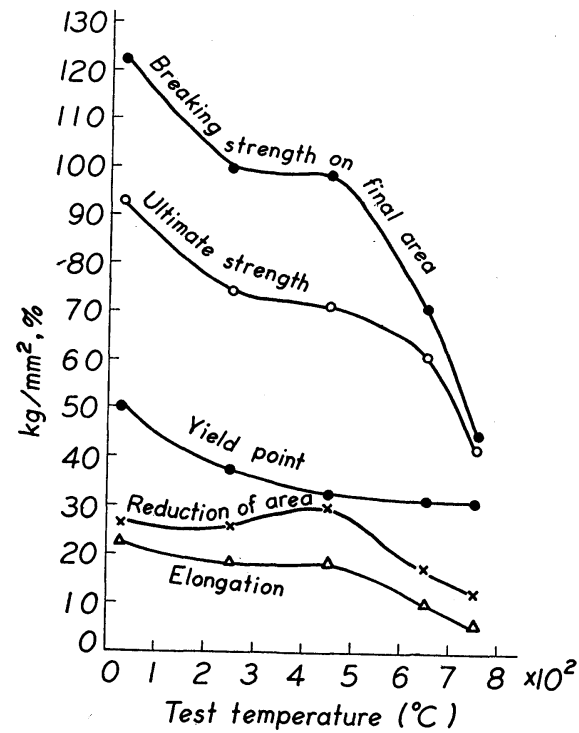

Fig. 14 Tensile properties of $\mathrm{SEH}_{4}(16 \mathrm{Cr}$, $14 \mathrm{Ni}, 3 \mathrm{~W}) 1180^{\circ} \mathrm{C} \times 5 \mathrm{hr}$ O.Q. $850^{\circ} \mathrm{C} \times$ 32hr A.C.

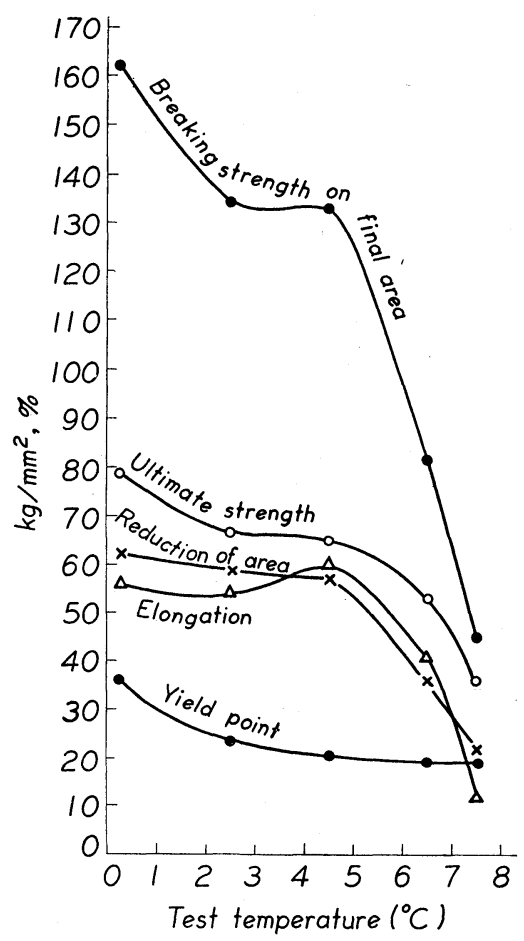

Fig. 15 Tensile properties of LCN 155 $1200^{\circ} \mathrm{C} \times 2$ hr O.Q. 


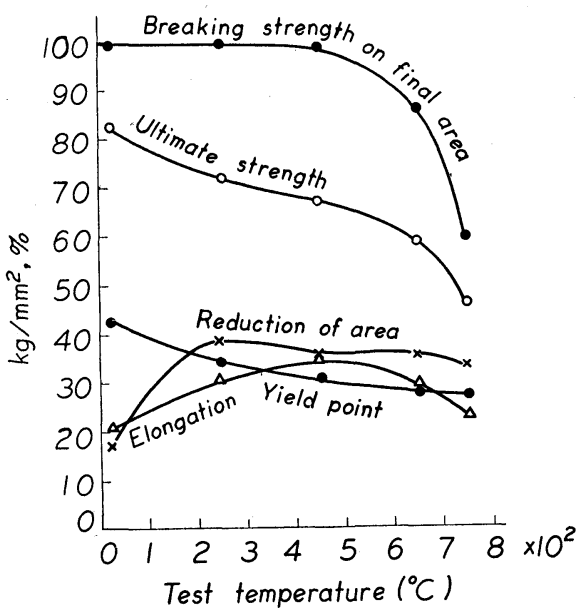

Fig. 16 Tensile properties of LCN $1551200^{\circ} \mathrm{C}$ $\times 2$ hr O.Q. $800^{\circ} \mathrm{C} \times 20$ hr A.C.

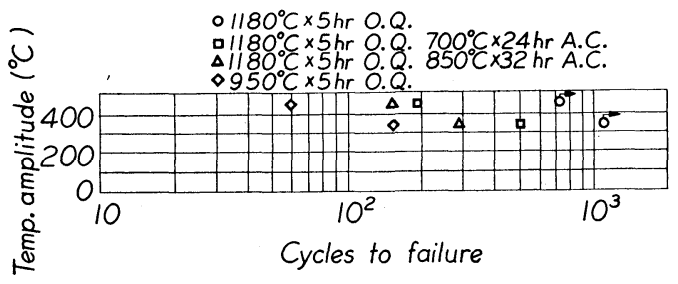

Fig. $17 \mathrm{SEH}_{4}(15 \mathrm{Cr}, 14 \mathrm{Ni}, 2 \mathrm{~W})$ thermal cycling (fixed at upper)

$\left\{650^{\circ} \mathrm{C}(5 \mathrm{~min})-300^{\circ} \mathrm{C}(2 \mathrm{~min})\right.$

$\left\{650^{\circ} \mathrm{C}(5 \mathrm{~min})-200^{\circ} \mathrm{C}(2 \mathrm{~min})\right.$

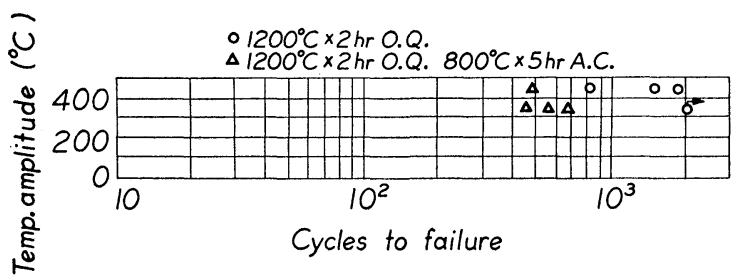

Fig. 18 Timken 16-25-6 thermal cycling (fixed at upper)

$\left\{650^{\circ} \mathrm{C}(5 \mathrm{~min})-300^{\circ} \mathrm{C}(2 \mathrm{~min})\right.$

$\left\{650^{\circ} \mathrm{C}(5 \mathrm{~min})-200^{\circ} \mathrm{C}(2 \mathrm{~min})\right.$

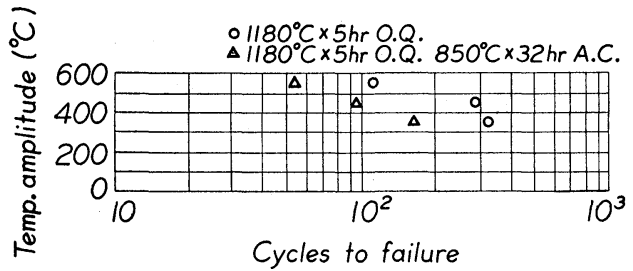

Fig. $19 \mathrm{SEH}_{4}(16 \mathrm{Cr}, 14 \mathrm{Ni}, 3 \mathrm{~W})$ thermal cycling (fixed at upper)

$650^{\circ} \mathrm{C}(15 \mathrm{~min})-300^{\circ} \mathrm{C}(5 \mathrm{~min})$

$\left\{650^{\circ} \mathrm{C}(15 \mathrm{~min})-200^{\circ} \mathrm{C}(5 \mathrm{~min})\right.$

$650^{\circ} \mathrm{C}(15 \mathrm{~min})-100^{\circ} \mathrm{C}(5 \mathrm{~min})$
よび加熱冷却の速さおよび試験材の弾塑性的性質の温 度依存度とうがあげられる。

筆書らは 3 種の耐熱鋼について最高試験温度を 650 ${ }^{\circ} \mathrm{C}$ 一定にして, 試験材の熱処理, 上, 下限の温度差,

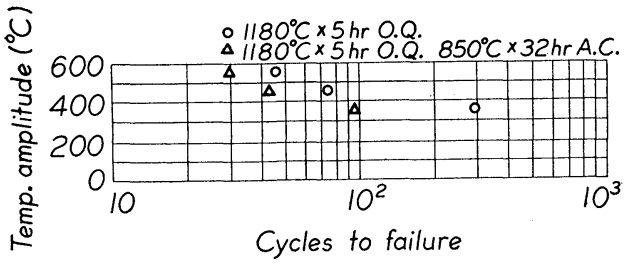

Fig. $20 \mathrm{SEH}_{4}(16 \mathrm{Cr}, 14 \mathrm{Ni}, 3 \mathrm{~W})$ thermal cycling (fixed at lower) $\left\{\begin{array}{l}300^{\circ} \mathrm{C}(5 \mathrm{~min})-650^{\circ} \mathrm{C}(15 \mathrm{~min}) \\ 200^{\circ} \mathrm{C}(5 \mathrm{~min})-650^{\circ} \mathrm{C}(15 \mathrm{~min}) \\ 100^{\circ} \mathrm{C}(5 \mathrm{~min})-650^{\circ} \mathrm{C}(15 \mathrm{~min})\end{array}\right.$

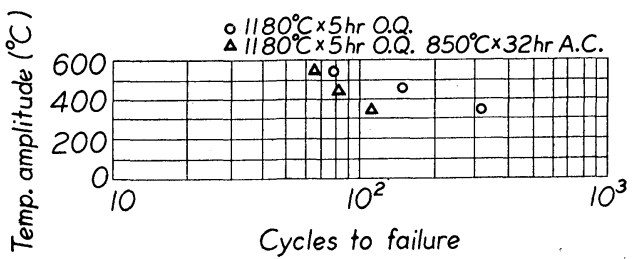

Fig. $21 \mathrm{SEH}_{4}(16 \mathrm{Cr}, 14 \mathrm{Ni}, 3 \mathrm{~W})$ thermal cycling (fixed at upper) $650^{\circ} \mathrm{C}(60 \mathrm{~min})-300^{\circ} \mathrm{C}(5 \mathrm{~min})$ $\left\{650^{\circ} \mathrm{C}(60 \mathrm{~min})-200^{\circ} \mathrm{C}(5 \mathrm{~min})\right.$ $650^{\circ} \mathrm{C}(60 \mathrm{~min})-100^{\circ} \mathrm{C}(5 \mathrm{~min})$

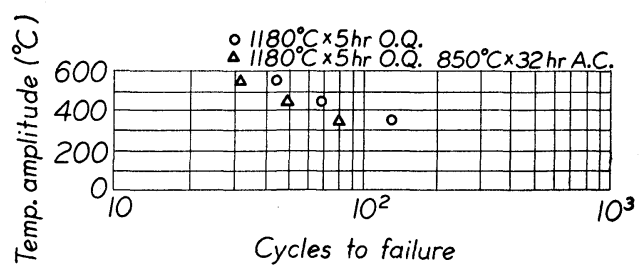

Fig. $22 \mathrm{SEH}_{4}(16 \mathrm{Cr}, 14 \mathrm{Ni}, 3 \mathrm{~W})$ thermal cycling (fixed at lower)

$300^{\circ} \mathrm{C}(5 \mathrm{~min})-650^{\circ} \mathrm{C}(60 \mathrm{~min})$ $\left\{200^{\circ} \mathrm{C}(5 \mathrm{~min})-650^{\circ} \mathrm{C}(60 \mathrm{~min})\right.$ $100^{\circ} \mathrm{C}(5 \mathrm{~min})-650^{\circ} \mathrm{C}(60 \mathrm{~min})$

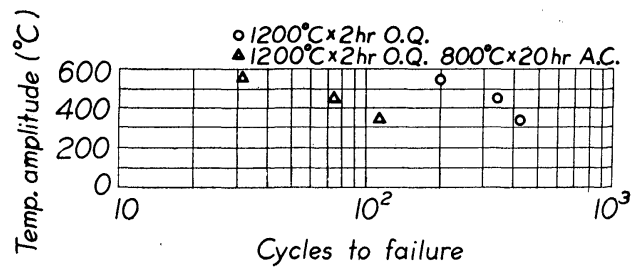

Fig. 23 LCN 155 thermal cycling (fixed at upper)

$\left\{\begin{array}{l}650^{\circ} \mathrm{C}(15 \mathrm{~min})-300^{\circ} \mathrm{C}(5 \mathrm{~min}) \\ 650^{\circ} \mathrm{C}(15 \mathrm{~min})-200^{\circ} \mathrm{C}(5 \mathrm{~min}) \\ 650^{\circ} \mathrm{C}(15 \mathrm{~min})-100^{\circ} \mathrm{C}(5 \mathrm{~min})\end{array}\right.$ 
上, 下限温度保持時間, 上, 下限温度における試験片 固定方法の相違などによる試験片破断回数に及ぼす影 響を調べた。

\section{（I） 供試材料}

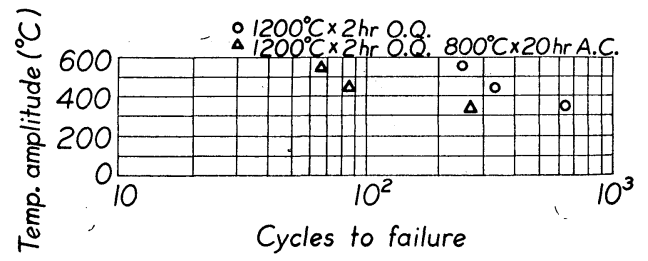

Fig. 24 LCN 155 thermal cycling (fixed at lower)

$\left\{\begin{array}{l}300^{\circ} \mathrm{C}(5 \mathrm{~min})-650^{\circ} \mathrm{C}(15 \mathrm{~min}) \\ 200^{\circ} \mathrm{C}(5 \mathrm{~min})-650^{\circ} \mathrm{C}(15 \mathrm{~min}) \\ 100^{\circ} \mathrm{C}(5 \mathrm{~min})-650^{\circ} \mathrm{C}(15 \mathrm{~min})\end{array}\right.$

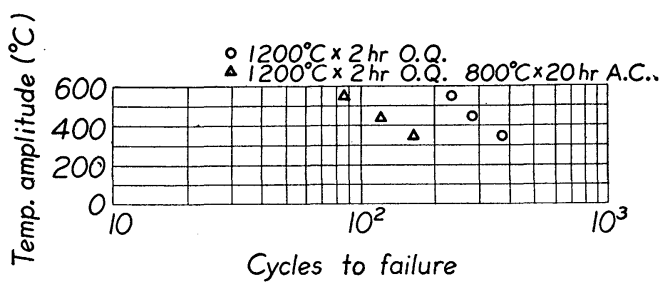

Fig. 25 LCN 155 thermal cycling (fixed at upper)

$\left(650^{\circ} \mathrm{C}(60 \mathrm{~min})-300^{\circ} \mathrm{C}(5 \mathrm{~min})\right.$ $650^{\circ} \mathrm{C}(60 \mathrm{~min})-200^{\circ} \mathrm{C}(5 \mathrm{~min})$ $650^{\circ} \mathrm{C}(60 \mathrm{~min})-100^{\circ} \mathrm{C}(5 \mathrm{~min})$

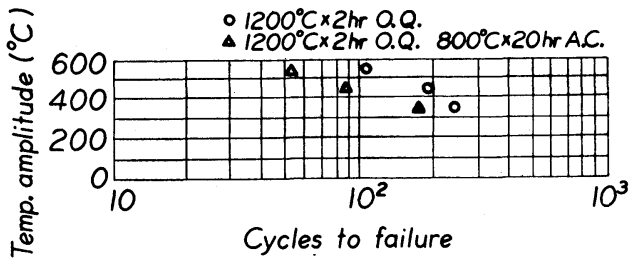

Fig. 26 LCN 155 thermal cycling (fixed at lower) $\left\{\begin{array}{l}300^{\circ} \mathrm{C}(5 \mathrm{~min})-650^{\circ} \mathrm{C}(60 \mathrm{~min}) \\ 200^{\circ} \mathrm{C}(5 \mathrm{~min})-650^{\circ} \mathrm{C}(60 \mathrm{~min}) \\ 100^{\circ} \mathrm{C}(5 \mathrm{~min})-650^{\circ} \mathrm{C}(60 \mathrm{~min})\end{array}\right.$

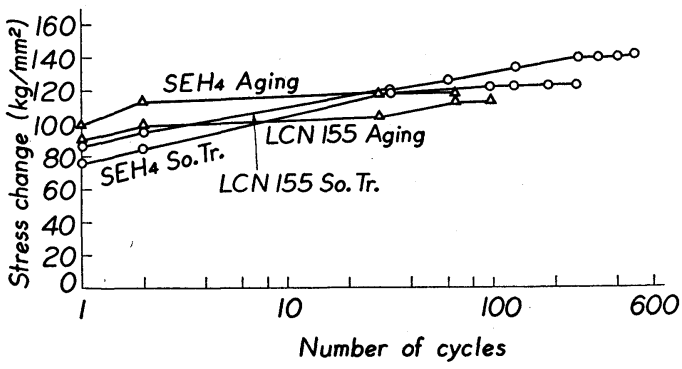

Fig. 27 Stress change for $650^{\circ} \mathrm{C}(15 \mathrm{~min})$ $300^{\circ} \mathrm{C}(5 \mathrm{~min})$ thermal cycling test
試験材料は $\mathrm{SEH}_{4}$ (A, B), Timken 16-25-6, LCN 155 の 3 種でそれらの分析成分および熱処理条件を

Table 1 に示し, Fig. 7〜16 に各材料の高温機械的性 質を示す. $\mathrm{SEH}_{4}$ に $\mathrm{A}, \mathrm{B}$ とあるのは鋼塊の種類が違 ったものである。熱処理は各材料とも固溶化処理のも のとこれを時效処理したものとに大別して選んだ.

\section{（II） 試験結果}

縦軸に温度振幅，横軸に試験片破断までの熱サイク ルの繰返回数をとって表わした試験結果を Fig. 17〜 Fig. 26 に示した. 図中でたとえば $650^{\circ} \mathrm{C}$ (15 分)一 $200^{\circ} \mathrm{C}$ (5 分) とあるのは上限温度 $650^{\circ} \mathrm{C}$ と下限温度 $200^{\circ} \mathrm{C}$ の繰り返しで上限温度における保持時間が 15 分 下限温度における保持時間が 5 分であり，かつはじめ

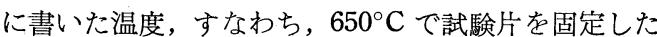
ものであることを表わしている，各試験とも試験片の 初締め付け応力は 0 にして行なった。試験中における 試験片応力の変化（1 サイクル中における最大引張応 力と最大圧縮応力の絶対值の和) の一例を Fig. 27, 28 に示した。

\section{4. 試験結果に対する考察}

間接加熱式繰返熱応力試験結果は以上のとおりであ るが，直接加熱式繰返熱応力試験および高温定ひずみ 繰返試験も同様な試験結果が得られている。各耐熱鋼 とも熱疲労強度は熱処理によっておおいに左右され， 回溶化処理だけのものが時效処理を行なったものに比 べ強いことが判明した. $\mathrm{SEH}_{4} \mathrm{~A}$ の熱処理 4 種につい ては焼鈍状態のものは熱疲労強度がもっとも低く, Max. aging 処理を行なったもの，Over aging処理の ものの順に強く固溶化処理のものがもっとも強くなっ ている. $\mathrm{SEH}_{4} \mathrm{~B}$, Timken 16-25-6, LCN 1552 種の 熱処理についても固溶化ままのものが時効したものよ り強い.これらの結果はクリープ破断試験によるもの とまったく逆な傾向であるが，これはクリープと熱疲 労との金属組織に与える変形機構の相違によるものと 考えられる。本報告には組織顕微鏡写真を揭げてない が，破断型式は粒内型と粒界型の両方で, Fransonの 熱疲労試験による約 $40 \%$ 粒界，約 $60 \%$ 粒内との結果 に対比される。

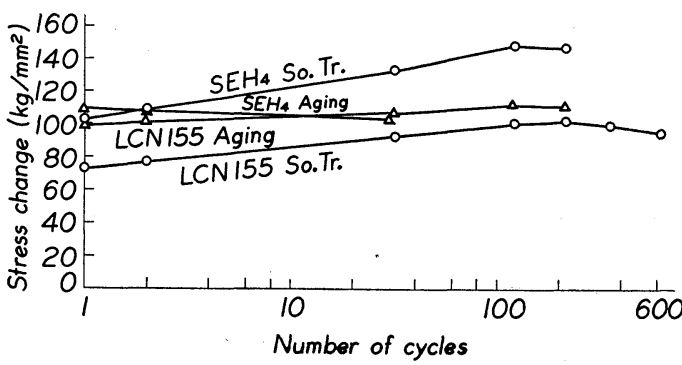

Fig. 28 Stress change for $300^{\circ} \mathrm{C}(5 \mathrm{~min})-$ $650^{\circ} \mathrm{C}(15 \mathrm{~min})$ thermal cycling test 
試験片の固定方法の相違による影響は，熱サイクル の上限温度で固定するか，下限温度で固定するかによ って熱サイクル中に生ずる応力の上限と下限の大きさ が異なるが，破断サイクル数には大差が認められなか ったのは Coffin の試験結果と同様である。熱疲労の 繰返速度に対する影響は速度が遅くなれば高温度に保 持される時間が長くなり，上限温度保持中にクリープ ならびに応力弛緩が起こる結果, ヒステリシス・ルー プが増大し, 繰返総塑性変形量が増すので寿命が短く なることになるが，Coffin はこれを実験的に確かめ ているもののデータにはかなりのばらつきが見受けら れる。本試験では上限温度保持時間を 3 種変えて行な ったが，その時間範囲では差異が認められなかった。 試験片の熱サイクル数の增加に伴なう応力変化は, 時 効処理のものはほぼ一定なのに対し, 固溶化のままの ものは応力が漸增してひずみ硬化していることがわか
る。

試験結果の表わし方として, 温度振幅に対する破断 回数をもってしたが, 熱サイクルが与えられれば試験 機の剛性によって繰り返しひずみ量が違うので, 温度 振幅の代わりに試験片の繰返全ひずみあるいは繰返塑 性ひずみ量をとるのが正しく，設計者にも有用である ので，その整理法その他を検討中である.

なお，これら試験機の一部は通産省釷工業技術試験 研究補助金の援助により完成されたものである.

\section{参考文 献}

1) L.F. coffin and R.P. Wesley, Trans. ASME., Vol. 76, p. 923 (1954)

2) L.F. Coffin, Trans. ASME, Vol. 76, 931 (1954)

3) L.F. Coffin, Trans. ASME, Vol. 78, 527 (1956)

4) L.F. Coffin, ASTM, STP, No 165, 31 (1954)

5）織田, 中島, 三菱造船材研課報, 第 593,634 号

6) A. Franson, Colloquim on Fatigue, Stockholm (1955)

\section{片持はり方式によるクリープ試験法}

[Recent Developments in Creep Testing by the Cantilever Bending Method, by G.T. Harris, H.C. Child, A.B. Collier and C.F. West, J.I.S.I. Vol. 190 (1958) PP 136/143]

著者がさきに (J.I.S.I. 1950) 精密鋳造あるいは粉末 冶金法によって製作しうる簡単な形の試験片により比 較的 Rough な試験をするために採用した片持はり方 式によるクリープ試験装置を改良して， $1000^{\circ} \mathrm{C} \sim$ $1200^{\circ} \mathrm{C}$ における精密試験をも行ないうるようにした ものについての報告である。旧試験装置では片持は り(長さ 8 in)のたわみを $1 / 100$ in 目もりのスケール で読んでいたものを，マイクロメーターと片持はりの 接触をネオンランプで検出して0.0001 in までの読み 取りを可能としている。 0.5 ton $/ \mathrm{in}^{2}$ 以下の低応力試 験に対しては 3 in のはりの自重のみにより負荷し, たわみの測定は $1: 1$ のレバーにより炉外に変位を取 り出してうえ同様の方法にて行なっている. 電気炉は 白金口ジューム炬で高温にさらされる部分の材料は G 39 (65 Ni-20 Cr-W-Mo-Nb) および W7 (75 Ni-17
Cr-Mo-Al-Nb) である。なお，このほか以上の装置 を Vacuum tube 中に封じ込んで真空中あるいは不 活性ガス中における試験を可能としたものについても 報告している。この試験法の有用性を証明するために 著者はチタニウム合金および 12 クロム鋼についての 曲げクリープ試験結果を Tapsell-Johnson の与えた 曲げクリープと引張クリープの関係式によって引張ク リープ試験結果と対比し，満足な一致（土10\%以内） が得られることを示している。著者はさらにこの種の 試験の利点としてクリープひずみの小さい場合の試験 法として少ない費用で目的を達しうること, 入手しう る材料の限られている場合小さい試験片による試験の 可能なこと，切削不可能で精密鋳造，粉末治金とうの 方法によらなければ試験片の製作が不可能な場合に試 験片の形が簡単であるという意味で有利であること, 真空中あるいは不活性ガス中での試験に対して簡単で 低廉な装置が用いうることなどの利点をあげ論議を行 なっている。

（小寺沢良一） 